\title{
PENGEMBANGAN E-MODULE BIOKIMIA PADA MATERI METABOLISME KARBOHIDRAT UNTUK MAHASISWA PROGRAM STUDI KIMIA
}

\author{
Siti Munawaroh ${ }^{1}$, Rara Seruni ${ }^{1}$, Muktiningsih Nurjayadi ${ }^{1^{*}}$ dan Fera Kurniadewi ${ }^{1}$ \\ ${ }^{1}$ Magister Pendidikan Kimia, fakultas Matematika dan ilmu Pengetahuan Alam, Universitas Negeri \\ Jakarta, Jl. Rawamangun Muka, RT.11/Rw.14, Rawamangun, Pulo Gadung, Kota Jakarta Timur, \\ Daerah Khusus Ibukota Jakarta 13220 \\ *Email: muktiningsih@unj.ac.id
}

\begin{abstract}
ABSTRAK
Pembelajaran abad 21 diarahkan berpusat pada peserta didik dan kemampuan untuk berkomunikasi, berkolaborasi, berpikir kritis, dan berkreativitas. Peserta didik harus dapat memanfaatkan teknologi secara maksimal. Latar belakang penelitian ini didasarkan pada kebutuhan bahan perkuliahan untuk sarana belajar mandiri dan dapat mengembangkan keterhubungan makroskopik, submikroskopik, dan simbolik. Penelitian ini bertujuan untuk menghasilkan e-module perkuliahan biokimia materi metabolisme karbohidrat untuk peserta didik program studi pendidikan kimia dan kimia semester VI. Di setiap akhir topik bahasan dalam modul ini terdapat tes formatif, sedangkan tes sumatif berada di akhir modul. Jenis penelitian yang digunakan adalah Research and Development model Borg dan Gall dengan instrumen berupa angket. Sumber data penelitian adalah mahasiswa pendidikan kimia berjumlah 36 orang dan 6 orang dosen. Data penelitian dikumpulkan melalui observasi terhadap peserta didik dan dosen biokimia. Berdasarkan hasil analisis data uji coba yang sudah divalidasi dapat diambil kesimpulan bahwa bahan ajar dalam bentuk e-modul yang dikembangkan sudah layak digunakan dalam perkuliahan Biokimia. Hal ini dibuktikan dari hasil validasi modul elektronik oleh ahli media, materi, dan bahasa diperoleh interpretasi baik dengan persentase $80 \%$ hingga $90 \%$ dan hasil uji coba skala kecil peserta didik dan dosen mendapatkan interpretasi baik dengan persentase $81 \%$ hingga $88 \%$.
\end{abstract}

Keywords: E-modul, biokimia, metabolisme karbohidrat

\begin{abstract}
Learning in $27^{\text {st }}$ century is directed to be student-centered to increase the ability to communicate, collaborate, critical thinking, and creativity. Students should be able to utilize the technology optimally. Background of this research was based on the necessity of learning materials for self learning and can develop connection between macroscopic, submicroscopic, and symbolic representation. This research aims to produce e-modules on biochemistry of carbohydrate metabolism material for students in Chemistry and Chemistry Education Study program semester VI. At the end of each topic in this module there was formative test, while the summative test is at the end of the module. The types of research used are Borg and Gall Research and Development models with research instruments in the form of a questionnaire. The source of research data was 36 students and 6 lecturers of Chemistry Education Study Program. Research Data is collected through observations of students and biochemistry lecturers. Based on the results of the analysis of the validated trial data can be concluded that the teaching materials in the form of e-modules are ready to be used in biochemical lecturing. This is evidenced by the validation results of electronic modules by media experts, material and language experts obtained good
\end{abstract}


interpretation with a percentage of $80 \%$ to $90 \%$ and the results of small-scale trial of students and lecturers get good interpretation with a percentage of $81 \%$ to $88 \%$.

Keywords: E-module, Biochemistry, carbohydrate metabolism

DOI: http://dx.doi.org/10.15575/jtk.v4i1.4679

\section{PENDAHULUAN}

Pendidikan merupakan hal yang sangat fundamental dalam meningkatkan kualitas kehidupan manusia dan menjamin perkembangan pembangunan bangsa. Dalam memasuki era perkembangan dan teknologi dewasa ini harus diimbangi dengan perkembangan kualitas manusia (Sudarsana, 2016). Seiring berubahnya sistem pendekatan pembelajaran dan bergesernya tujuan pendidikan, karakteristik pembelajaran abad 21 (Permendikbud nomor 103 Tahun 2015) menuntut pendekatan pembelajaran yang berpusat pada peserta didik (student centered learning). Hal ini sesuai dengan tuntutan dunia masa depan peserta didik harus memiliki kecakapan berpikir dalam belajar. Kecakapankecakapan tersebut diantaranya adalah kecakapan memecahkan masalah (problem solving), berpikir kritis, kolaborasi, dan kecakapan berkomunikasi. Semua kecakapan ini bisa dimiliki oleh peserta didik apabila pendidik mampu mengembangkan pembelajaran yang mengarahkan peserta didik pada kegiatan-kegiatan yang dapat meningkatkan kemampuan peserta didik untuk berpikir kritis dalam memecahkan masalah.

Banyaknya hambatan yang menjadi kendala atas kelancaran kegiatan belajar. Kecenderungan kurangnya minat membaca, sesuai hasil survei United Nations Educational, Scientific, and Cultural Organization (UNESCO) tahun 2011 yang menunjukkan indeks tingkat membaca masyarakat Indonesia hanya 0,001 persen, atau hanya ada satu orang dari 1000 penduduk yang mau membaca buku secara serius (Nurchaili, 2017). Kecenderungan kurangnya minat membaca buku pada peserta didik karena lebih menyukai membaca menggunakan media elektronik. Media mengajar yang digunakan kurang menarik minat belajar peserta didik, karena dengan menggunakan media pembelajaran yang tepat akan mampu merangsang motivasi belajar peserta didik (Abustan \& Nawir, 2018). Padatnya materi yang harus disampaikan, sempitnya waktu perkuliahan, serta kesulitan peserta didik mencari informasi pembelajaran melalui media elektronik yang disebabkan kurangnya pemahaman peserta didik dalam menggunakan atau memanfaatkan media elektronik (Widalismana \& Lestari, 2017). Faktor-faktor di atas merupakan penyebab tidak tercapainya tujuan pembelajaran yang telah ditetapkan secara maksimal. Dengan adanya berbagai hambatan tersebut, diperlukan pengelolaan dan strategi pembelajaran yang baik untuk meningkatkan kualitas pembelajaran serta mencapai tujuan pembelajaran yang optimal dalam mata kuliah biokimia materi metabolisme karbohidrat.

Berdasarkan hasil analisis pendahuluan terhadap peserta didik Universitas Negeri Jakarta program studi pendidikan kimia dan kimia semester VI yang sudah disebar melalui google form dari 59 responden diperoleh hasil $99 \%$ menginginkan bahan ajar lain selain buku kuliah dan 99\% juga mengharapkan adanya video pembelajaran mata kuliah Biokimia pada materi metabolisme karbohidrat. Penelitian 
S. Munawaroh, R. Seruni, M. Nurjayadi, \& F. Kurniadewi

lain yang juga mendukung pentingnya penggunaan pembelajaran dengan bantuan e-module sebagai sarana komunikasi yang lebih efektif sehingga dapat meningkatkan hasil belajar peserta didik yang ditunjukkan melalui naiknya nilai rata-rata kelas pada siklus I dan siklus II (Eli \& Sari, 2018). Diperkuat juga oleh penelitian Sari \& Samawi (2014) mengenai pengaruh media animasi terhadap hasil belajar IPA, peserta didik slow learner menunjukkan hasil adanya peningkatan pemahaman peserta didik terhadap mata pelajaran IPA dengan kategori baik. (Osman \& Lee, 2014) menyebutkan bahwa penelitian yang mendesain dan mengembangakan IMMPA (Interactive Multimedia Module With Pedagogical Agents) menunjukkan peningkatan yang signifikan secara statistik dari nilai tes dan skor rata-rata motivasi belajar terhadap kelas yang pembelajaran elektrokimia menggunakan e-modul dibanding kelas konvensional.

Salah satu media ajar yang dapat digunakan peserta didik untuk belajar mandiri adalah dalam bentuk modul (Munadi, 2012). Prastowo (2013) menyebutkan bahwa modul merupakan sebuah bahan ajar yang disusun secara sistematis dengan menggunakan bahasa yang dapat dengan mudah dipahami oleh peserta didik serta dapat dipelajari secara mandiri tanpa hadirnya fasilitator dan modul juga dapat digunakan sesuai dengan tingkat kemampuan pemahaman belajar peserta didik. Adapun modul ajar yang sekarang sesuai dengan perkembangan teknologi adalah berbasis elektronik (Putra dkk., 2017). E-Module merupakan media pembelajaran (modul) dengan menggunakan laptop/desktop yang menampilkan teks, gambar, grafik, audio, animasi, dan video dalam proses pembelajaran (Sitepu, 2014). Emodule ini digunakan secara off line atau on line dan juga dapat mengembangkan keterhubungan makroskopik, submikroskopik,
Pengembangan E-Module Biokimia pada Materi Metabolisme Karbohidrat untuk Mahasiswa Program Studi Kimia

dan simbolik. Representasi makroskopik penyajiannya dalam bentuk wacana fenomena kontekstual, representasi submikroskopik divisualisasikan melalui gambar dan video yang keterhubungannya disajikan dalam bentuk representasi simbolik. Kelebihan lain dari bentuk penyajian e-modul ini ukuran file yang relatif kecil, mudah dibawa hanya menggunakan USB/Flashdisk (Romiati, 2018).

Berdasarkan penjelasan di atas, nampak bahwasanya e-modul memiliki potensi yang sangat besar untuk digunakan dalam proses perkuliahan biokimia materi metabolisme karbohidrat karena dapat memvisualisasikan keabstrakan materi metabolisme karbohidrat dan juga sesuai dengan karakteristik dari emodul yang dirancang khusus untuk sarana belajar mandiri dan menarik, ditambah lagi dengan beberapa keunggulan format elektronik karena menggunakan aplikasi yang paling baru dan sangat memungkinkan untuk mengintegrasikan berbagai simulasi video tutorial dalam penyajian materi teknis dan proses evaluasinya. Selain itu, modul elektronik ini juga dapat menyajikan informasi secara lebih terstruktur, serta memiliki sistem navigasi yang memudahkan bagi peserta didik menelusuri materi sesuai dengan kecakapan belajarnya masing-masing (Zaningsih, 2018). Belajar menggunakan modul sangat banyak manfaatnya, peserta didik dapat bertanggung jawab terhadap kegiatan belajarnya sendiri, pembelajaran dengan modul sangat menghargai perbedaan individu, sehingga peserta didik dapat belajar sesuai dengan tingkat kemampuannya, maka pembelajaran semakin efektif dan efisien (Sirate dan Ramadhana, 2017).

Oleh karena itu penelitian ini dilaksanakan untuk mengembangkan e-modul materi metabolisme karbohidrat pada mata kuliah biokimia dengan aplikasi yang digunakan adalah PDF Flip Page Professional. Dengan 
S. Munawaroh, R. Seruni, M. Nurjayadi, \& F. Kurniadewi

adanya PDF Flip Page Professional, kita dapat membuat video yang ditampilkan berbentuk tiga dimensi, navigasi yang lengkap, efek membalik modul digital lebih nyata, serta tampilan video yang lebih jelas, terdapat lembar jawaban tersendiri untuk menjawab soal latihan dan kesimpulan, dapat digunakan untuk pembelajaran jarak jauh secara mandiri, dan perolehan hasil tes formatif dapat langsung dilihat skornya oleh peserta didik. Fokus dari pengembangan terletak pada bentuk penyajian mandiri dan menarik yang di dalamnya terdapat pengelolaan materi, pengelolaan tampilan, dan uji tes formatif serta tes sumatif untuk mengukur ketercapaian pembelajaran.

\section{METODE PENELITIAN}

Metode yang digunakan adalah penelitian dan pengembangan (Research \& Development) produk pendidikan Borg \& Gall (2006). Penelitian yang dilakukan bertujuan untuk menghasilkan modul elektronik biokimia untuk materi metabolisme karbohidrat. Subjek penelitian ini adalah mahasiswa Program Studi Pendidikan Kimia dan Kimia pada September 2018 - April 2019. Tahapan penelitian ini dapat dikelompokkan menjadi:

\subsection{Tahapan pendahuluan}

Dilakukan dengan analisis pendahuluan dan kebutuhan yang dimaksudkan untuk memperoleh informasi tentang kondisi pembelajaran biokimia, serta mengetahui kebutuhan peserta didik dan dosen terhadap bahan penunjang pembelajaran biokimia, sehingga menarik dan dapat meningkatkan kemandirian peserta didik dalam mempelajari metabolisme karbohidrat.

\subsection{Tahapan Perencanaan}

Tahap ini bertujuan untuk menghasilkan produk e-Module yang layak dan sesuai digunakan sebagai sumber belajar peserta
Pengembangan E-Module Biokimia pada Materi Metabolisme Karbohidrat untuk Mahasiswa Program Studi Kimia

didik serta sebagai bahan ajar alternatif dosen. Pada tahapan ini terdiri dari kegiatan menganalisis capaian pembelajaran mata kuliah, menentukan aplikasi-aplikasi yang dapat digunakan, serta menentukan kualifikasi pihak-pihak yang terlibat dalam pengembangan e-Module.

\subsection{Tahap Pengembangan}

Tahap ini bertujuan untuk menghasilkan produk e-Module yang layak dan sesuai dengan kurikulum nasional berbasis Kerangka Kualifikasi Nasional Indonesia. Pada tahapan ini, dimulai dari pembuatan cover, penyusunan isi materi yang disertai gambar dan video.

\subsection{Tahap Validasi}

Pada tahapan validasi oleh para ahli ini bertujuan untuk mendapatkan penilaian dan saran dari para ahli yang terdiri dari ahli materi, ahli bahasa, dan ahli media. Hal ini berguna untuk pengembangan e-Module yang lebih baik. Setelah mendapatkan penilaian dari para ahli, dilakukan revisi produk e-Module sesuai dengan masukan-masukan dari para ahli. Selanjutnya e-Module tersebut diuji dengan menggunakan skala kecil yang berjumlah 20 orang peserta didik sebelum diujikan pada skala besar pada peserta didik prodi pendidikan kimia dan kimia yang telah diobservasi sebelumnya. Data hasil uji coba tersebut dijadikan masukan untuk perbaikan e-Module. Setelah dilakukan revisi berdasarkan uji skala kecil maka dilakukan implementasi produk kepada peserta didik yang sedang belajar biokimia materi metabolisme karbohidrat.

Instrumen yang dipakai pada penelitian ini adalah: Instrumen analisis pendahuluan dan kebutuhan, berisi pernyataan yang diajukan kepada peserta didik maupun dosen. Hal ini bertujuan untuk mengetahui kebutuhan dan kondisi peserta didik dalam pembelajaran kimia serta mengetahui kebutuhan e-Module 
S. Munawaroh, R. Seruni, M. Nurjayadi, \& F. Kurniadewi

dalam pembelajaran kimia khususnya pada materi metabolisme karbohidrat, agar yang dikembangkan sesuai dengan kebutuhan. Instrumen ini juga merupakan referensi untuk langkah berikutnya. Instrumen ini menggunakan skala Guttman. Skala Guttman adalah skala pengukuran yang akan diperoleh jawaban tegas yaitu "ya" atau "tidak". Instrumen validasi oleh para ahli dibuat untuk menilai kesesuaian e-Module dan memperoleh masukan dari para ahli dalam perbaikan eModule yang menggunakan instrumen validasi dari para ahli media (berasal dari orang yang ahli IT/media dan berkecimpung di dunia pendidikan) dan ahli materi sekaligus ahli bahasa (dosen).

Instrumen uji coba peserta didik dan dosen yang sebagai subjek penelitian dan yang akan menggunakan produk e-Module pembelajaran Biokimia yaitu berupa angket analisis pendahuluan; angket uji ahli materi, bahasa, dan media. Selanjutnya data yang diperoleh dianalisis secara deskriptif, dihitung menggunakan rating scale. Berdasarkan hasil analisis instrumen ini diperoleh kelayakan baik dan buruknya e-Module pembelajaran
Pengembangan E-Module Biokimia pada Materi Metabolisme Karbohidrat untuk Mahasiswa Program Studi Kimia

Biokimia dengan kriteria interpretasi skor rentang $0-100 \%$ yang dapat dilihat pada Tabel 1.

Tabel 1. Tabel interpretasi skor

\begin{tabular}{|c|c|}
\hline Skor & Kriteria \\
\hline $91 \% \leq x \leq 100 \%$ & Sangat Baik \\
\hline $76 \% \leq x \leq 90 \%$ & Baik \\
\hline $56 \% \leq x \leq 75 \%$ & Cukup \\
\hline $41 \% \leq x \leq 55 \%$ & Kurang \\
\hline $0 \% \leq x \leq 40 \%$ & Jelek \\
\hline
\end{tabular}

\section{HASIL DAN PEMBAHASAN}

Penelitian ini adalah menghasilkan e-module biokimia untuk materi metabolisme karbohidrat menggunakan aplikasi PDF Flip Page Professional ditinjau dari ahli materi, bahasa, dan media serta uji coba lapangan. Hasil validasi menunjukkan e-module yang dikembangkan memenuhi kriteria dari aspek materi, bahasa, dan kegrafikan.

Kelayakan e-module yang dikembangkan ini didasarkan pada hasil angket penilaian $e$ module oleh dosen dan peserta didik pada saat uji kelayakan e-module. Hasilnya dapat dilihat pada Tabel 2, Tabel 3, dan Tabel 4.

Tabel 2. Hasil perbandingan instrumen validasi e-module komponen isi dan kebahasaan

\begin{tabular}{|c|c|c|c|c|}
\hline \multirow{2}{*}{ No } & \multirow{2}{*}{ Indikator } & Ahli 1 & Ahli 2 & Ahli 3 \\
\hline & & $\%$ & $\%$ & $\%$ \\
\hline \multicolumn{5}{|l|}{ Isi } \\
\hline 1 & Cakupan Materi & 83 & 90 & 80 \\
\hline 2 & Keakuratan Materi & 80 & 80 & 90 \\
\hline 3 & Keterampilan & 90 & 90 & 80 \\
\hline \multicolumn{5}{|c|}{ Kebahasaan } \\
\hline 4 & Sesuai dengan perkembangan peserta didik & 85 & 85 & 80 \\
\hline 5 & Komunikatif & 90 & 85 & 75 \\
\hline 6 & Kemampuan memotivasi & 90 & 90 & 85 \\
\hline 7 & Kelugasan & 90 & 85 & 85 \\
\hline 8 & Koherensi dan keruntutan alur pikiran & 90 & 90 & 80 \\
\hline 9 & Kesesuaian dengan EYD & 90 & 85 & 80 \\
\hline 10 & Penggunaan istilah dan simbol/lambang kimia & 90 & 90 & 80 \\
\hline
\end{tabular}


S. Munawaroh, R. Seruni, M. Nurjayadi, \& F. Kurniadewi

Tabel 3. Hasil perbandingan instrumen validasi e-module komponen kegrafikan

\begin{tabular}{|c|c|c|c|c|}
\hline No & Indikator & $\begin{array}{c}\text { Ahli } \\
1\end{array}$ & $\begin{array}{c}\text { Ahli } \\
2\end{array}$ & $\begin{array}{c}\text { Ahli } \\
3\end{array}$ \\
\hline & & $\%$ & $\%$ & $\%$ \\
\hline \multicolumn{5}{|c|}{ Cover $e$-modul } \\
\hline 1 & Desain Cover & 79 & 84 & 85 \\
\hline 2 & $\begin{array}{l}\text { Tipografi cover } e^{-} \\
\text {modul }\end{array}$ & 83 & 87 & 80 \\
\hline 3 & $\begin{array}{l}\text { llustrasi cover } e^{-} \\
\text {modul }\end{array}$ & 83 & 87 & 83 \\
\hline \multicolumn{5}{|c|}{ Desain isi e-modul } \\
\hline 4 & $\begin{array}{l}\text { Tata letak isi } e- \\
\text { modul }\end{array}$ & 78 & 86 & 86 \\
\hline 5 & $\begin{array}{l}\text { Tipografi } e^{-} \\
\text {modul }\end{array}$ & 82 & 85 & 83 \\
\hline 6 & $\begin{array}{l}\text { Ilustrasi isi } e- \\
\text { modul }\end{array}$ & 80 & 84 & 88 \\
\hline
\end{tabular}

Tabel 4. Hasil uji skala kecil e-modul pada peserta didik

\begin{tabular}{|c|l|c|c|}
\hline No & \multicolumn{1}{|c|}{ Indikator } & \multicolumn{1}{c|}{ Interpretasi } \\
\hline 1 & $\begin{array}{l}\text { Kesesuaian } \\
\text { materi e-module }\end{array}$ & 88,17 & Baik \\
\hline 2 & $\begin{array}{l}\text { Kejelasan isi e- } \\
\text { module }\end{array}$ & 82,40 & Baik \\
\hline 3 & $\begin{array}{l}\text { Fungsi soal } \\
\text { sebagai alat } \\
\text { evaluasi }\end{array}$ & 81,50 & Baik \\
\hline 4 & Bahasa & 80,50 & Baik \\
\hline 5 & Desain tampilan & 82,80 & Baik \\
\hline
\end{tabular}

Salah satu fungsi pengembangan e-module yaitu sebagai sumber belajar mandiri peserta didik (Prasetiyowati, 2015). Ahli materi, bahasa, dan media melakukan validasi tahap awal produk. Hasil validasi dapat dilihat pada tabel 2, didapatkan nilai $85,43 \%$ dengan interpretasi baik. Terdapat beberapa revisi Salah satu fungsi pengembangan $E$-modul yaitu sebagai sumber belajar mandiri peserta didik (Prasetiyowati, 2015). Ahli materi, bahasa, dan media melakukan validasi tahap awal produk. Hasil validasi dapat dilihat pada tabel 2, didapatkan nilai $85,43 \%$ dengan interpretasi baik. Terdapat beberapa revisi berdasarkan
Pengembangan E-Module Biokimia pada Materi Metabolisme Karbohidrat untuk Mahasiswa Program Studi Kimia

masukan dari ahli materi dan bahasa. Emodule yang dikembangkan tidak hanya berisi konsep materi saja, melainkan berisi gambargambar dan video. Hal ini sesuai dengan hasil penelitian dari Toprak (2011) menunjukkan pemberian analogi dengan visualisasi gambar sangat dibutuhkan dalam proses pembelajaran terutama untuk konsep kimia yang abstrak. Hasil validasi ahli media dapat dilihat pada Tabel 3, didapatkan nilai 83,5\% dengan interpretasi baik. Terdapat beberapa revisi berdasarkan masukan dari ahli media terkait penempatan gambar dan pemilihan warna untuk background.

Tabel 3 merupakan hasil uji coba lapangan menggunakan angket respon peserta didik terhadap e-module dan diperoleh nilai ratarata $83,07 \%$ dengan interpretasi baik. Berdasarkan hasil analisis tersebut menunjukkan bahwa e-module yang dikembangkan layak digunakan untuk pembelajaran biokimia materi metabolisme karbohidrat.

Berdasarkan penelitian sebelumnya pengembangan e-module yang memiliki tahapan dan ketentuan-ketentuan yang cukup banyak (Purwaningtyas dkk., 2017) sedangkan dalam penelitian ini menggunakan PDF Flip Page Professional yang lebih ringkas dan memiliki kelebihan seperti tampilan yang sangat menarik sehingga menarik minat baca peserta didik, akses untuk membuka modul sangat mudah, seperti penelitian sebelumnya (Rachmah dkk., 2018) yang berjudul "Pengembangan Modul Elektronik Berbasis 3D PageFlip Professional pada Materi Usaha dan Energi".

Aplikasi PDF Flip Page Professional yang peneliti pergunakan memungkinkan dapat melaksanakan tes formatif dan tes sumatif yang dihubungkan ke e-mail dosen, dengan 
S. Munawaroh, R. Seruni, M. Nurjayadi, \& F. Kurniadewi

tipe soal yang beraneka ragam, bisa berupa pilihan ganda, isian, esai, ataupun pilihan benar-salah, dengan demikian dosen dapat melihat tingkat ketercapaian pembelajaran.

\section{KESIMPULAN}

Berdasarkan hasil analisis data dan pembahasan yang telah dilakukan dapat disimpulkan bahwasanya tampilan e-module biokimia materi metabolisme karbohidrat menarik dan komunikatif serta sudah layak digunakan untuk pembelajaran perkuliahan. Hal ini dibuktikan dari hasil persentase ratarata validasi oleh ahli materi dan bahasa $86 \%$ dan persentase rata-rata validasi oleh ahli media $84 \%$, persentase rata-rata respon peserta didik pada saat uji coba lapangan skala kecil diperoleh $83 \%$.
Pengembangan E-Module Biokimia pada Materi Metabolisme Karbohidrat untuk Mahasiswa Program Studi Kimia 
S. Munawaroh, R. Seruni, M. Nurjayadi, \& F. Kurniadewi

\section{DAFTAR PUSTAKA}

Abustan, A., \& Nawir, N. (2018). Pengaruh Penggunaan Media Elektronik LCD terhadap Prestasi Belajar IImu Pengetahuan Sosial Siswa Kelas V. JRPD (Jurnal Riset Pendidikan Dasar), 1(1), 3439.

Borg, W.R, \& Gall, M. D. (2006). Educational Research: An Introduction, (Eighth Edi). New York \& London: Pearson Education.

Eli, R. N., \& Sari, S. (2018). Pembelajaran Sistem Koloid melalui Media Animasi untuk Meningkatkan Aktivitas dan Hasil Belajar Siswa. Jurnal Tadris Kimiya, 3(2), 135144.

Munadi, Y. (2012). Media Pembelajaran. Jakarta: Gaung Persada Press.

Nurchaili, N. (2017). Menumbuhkan Budaya Literasi Melalui Buku Digital. LIBRIA, 8(2).

Osman, K., \& Lee, T. T. (2014). Impact Of Interactive Multimedia Module With Pedagogical Agents On Students' Understanding And Motivation In The Learning Of Electrochemistry. International Journal of Science and Mathematics Education, 12(2), 395-421.

Prasetiyowati, Y. (2015). Pengembangan Modul Elektronik pada Mata Pelajaran Animasi 3 Dimensi Materi Pokok Pemodelan Objek 3D Kelas XI Multimedia untuk Meningkatkan Hasil Belajar di Smk Negeri 1 Magetan. Jurnal Mahasiswa Teknologi Pendidikan, 6(2).

Prastowo, A. (2013). Panduan Kreatif Membuat Bahan Ajar Inovatif; Menciptakan Metode Pembelajaran Yang Menarik Dan
Pengembangan E-Module Biokimia pada Materi Metabolisme Karbohidrat untuk Mahasiswa Program Studi Kimia

Menyenangkan, cet. Yogyakarta: Diva Press.

Purwaningtyas, Dwiyogo, W. D., \& Hariyadi, I. (2017). Pengembangan Modul Elektronik Mata Pelajaran Pendidikan Jasmani, Olahraga, dan Kesehatan Kelas $\mathrm{XI}$ berbasis Online dengan Program Edmodo. Jurnal Pendidikan, 2(1),121129.

Putra, K. W. B., Wirawan, I. M. A., \& Pradnyana, G. A. (2017). Pengembangan E-Modul Berbasis Model Pembelajaran Discovery Learning Pada Mata Pelajaran "Sistem Komputer" Untuk Siswa Kelas X Multimedia Smk Negeri 3 Singaraja. Jurnal Pendidikan Teknologi Dan Kejuruan, 14(1), 40-49.

Rachmah, A., Rosha, J. M., \& Vani, N. D. (2018). Pengembangan Modul Elektronik Berbasis 3D PageFlip Professional pada Materi Usaha dan Energi. Physics Education, 1(2), 1-11.

Romiati, S. (2018). Pengembangan E-Module Pembelajaran Kimia Pada Materi Kelarutan Dan Hasil Kali Kelarutan Dengan Pendekatan Saintifik Untuk Meningkatkan Kemampuan Pemecahan Masalah Siswa. Universitas Negeri jakarta.

Sari, N. W., \& Samawi, A. (2014). Pengaruh Penggunaan Media Animasi Terhadap Hasil Belajar Ipa Siswa Slow Learner. Jurnal Penelitian dan Pengembangan Pendidikan Luar Biasa, 1(2), 140-144.

Sirate, S. F. S., \& Ramadhana, R. (2017). Pengembangan Modul Pembelajaran Berbasis Keterampilan Literasi. Inspiratif Pendidikan, 6(2), 316-335. 
S. Munawaroh, R. Seruni, M. Nurjayadi, \& F. Kurniadewi

Sitepu. (2014). Pengembangan Sumber Belajar. Jakarta: Raja Grafindo Persada.

Sudarsana, I. K. (2016). Peningkatan Mutu Pendidikan Luar Sekolah dalam Upaya Pembangunan Sumber Daya Manusia. Jurnal Penjaminan Mutu, 1(1), 1-14.

Toprak, M. (2011). An analysis of analogies used in secondary chemistry textbooks. Procedia Computer Science, 3, 307-311.

Widalismana, M., \& Lestari, N. D. (2017). Analisis Hasil Belajar Mahasiswa menggunakan Media Cetak dengan Media Elektronik pada Mata Kuliah Matematika Ekonomi di Universitas PGRI. PINUS: Jurnal Penelitian Inovasi Pembelajaran, 3(1), 41-48.

Zaningsih, R. D. (2018). Pengembangan Aplikasi E-Modul Mobile Pembelajaran Matematika Berbasis Android Studio Pokok Bahasan Matriks (Doctoral dissertation, UIN Raden Intan Lampung).
Pengembangan E-Module Biokimia pada Materi Metabolisme Karbohidrat untuk Mahasiswa Program Studi Kimia 